\title{
ANALISIS PREFERENSI MASYARAKAT TERHADAP RESTORAN CEPAT SAJI DI KOTA BOGOR
}

\author{
Sri Hartini dan Lesti Hartati \\ Fakultas Ekonomi Universitas Pakuan \\ E-mail: srihartini068@gmail.com
}

\begin{abstract}
The objectives of this research are: (1) to identify the most important environmental factors that led to a variety of consumer preferences for fast food restaurants in Bogor; (2) to measure the relative performance of consumer satisfaction attribute in fast food restaurant industry in Bogor by using approach of importance performance analysis; and (3) to identify the pattern of competition among fast food restaurants in Bogor City with the use of SPSS scoring method. Data analysis method used is Fischbein analysis consist of quantitative analysis and qualitative analysis. The results showed that: 1) hygiene factors should be put forward because the concept of fast food restaurants attract more consumers from middle to upper economic level, and of course it is critical to give an assessment of the condition or circumstances in all aspects of the service from fast food restaurants; 2) the level of service provided to the consumer most attributes are in the low priority position matrix with the percentage of 53\%, the attribute on the matrix to maintain the achievement is in the second with the percentage of $33 \%$, followed by the main priority attribute is only $9 \%$ and the last attribute on the matrix excessive with percentage of $5 \%$. This means there are still many attributes that do not have significant effectiveness to the services provided by each attribute; 3) can be determined the average total scoring of KFC restaurant (20.56, 14\%), McD restaurant (18.29, 12\%), Pizza Hut restaurant (16.67, 11\%), Trio restaurant (15.98,11\%), restaurant of Simpang Raya (15.96,11\%), Burger Kings restaurant(15.87,10\%, Rumah Anai restaurant, $(15.18 ; 10 \%)$, and Dominos restaurant $(14.83,10 \%)$.
\end{abstract}

\section{Keywords: Community Preference, Fast Food Restaurant, and Bogor City}

\section{PENDAHULUAN \\ Latar Belakang \\ Perubahan pada pola konsumsi masyarakat yang beraneka ragam, memunculkan konsep penghidangan makanan yang praktis, salah satunya adalah jenis fast food (makanan cepat saji). Peluang usaha ini dimanfaatkan oleh banyak pemilik modal. Rumah makan cepat saji (bahasa Inggris: fast food restaurant) adalah rumah makan yang menghidangkan makanan dan minuman dengan cepat, biasanya dalam waktu kurang dari 3 menit. Umumnya berupa kedai hamburger atau ayam goreng, kedai bakso, rumah makan padang juga dikategorikan sebagai rumah makan cepat saji. Umumnya rumah makan jenis ini}

merupakan rantai bisnis (franchise), dengan operasi pelayanan yang standar, seragam. Sifat pelayanan yang standar ini menjadikan restoran atau rumah makan sejenis ini biasanya menjadi pilihan wisatawan yang belum mengetahui kondisi wilayah yang dikunjunginya.

Selain kota singgah, Kota Bogor adalah kota destinasi pariwisata. Para pengunjung kota akan menempatkan rumah makan cepat saji sebagai pilihan pertama. Peluang ini dimanfaatkan oleh banyak pemilik modal dalam industri restoran cepat saji. Dalam persaingan yang semakin ketat, banyak upaya yang dilakukan oleh perusahaan. Namun salah satu yang dirasakan paling penting adalah memahami perilaku konsumen dan 
karakteristik konsumen secara umum. Hal ini dapat bermanfaat bagi perusahaan karena konsumsi produk setiap wilayah berbeda satu sama lain. Perusahaan juga perlu mengetahui posisi relatif dibandingkan dengan para pesaingnya. Sebagai contoh, misalnya dalam bisnis ayam goreng, Kentucky Fried Chicken, Mc. Donald's, Texas Fried Chicken dan California Fried Chicken dan lainnya.

Pemasaran merupakan ujung tombak dari perusahaan. Tanpa fungsi pemasaran yang berjalan dengan baik, perusahaan akan berjalan tersendat dan tak tentu arah. Tanpa memahami pasar dan konsumen, perusahaan akan sulit menempatkan produknya di pasar. Salah satu fungsi dari pemasaran adalah memahami preferensi dan karakteristik konsumen.

Mengingat pentingnya memahami preferensi konsumen terhadap makanan cepat saji, agar perusahaan dapat menyusun strategi agar produknya itu bisa diterima oleh konsumen, diperlukan penelitian mengenai preferensi konsumen terhadap makanan cepat saji, agar pola persaingan di antara perusahaan-perusahaan ini dapat tergambarkan.

\section{Perumusan Masalah}

Berdasarkan latar belakang di atas, maka dapat dirumuskan permasalahan dalam penelitian ini adalah sebagai berikut:

1. Bentuk persaingan dapat dilihat dari siapa yang bersaing. Persaingan dapat terjadi antara konsumen-konsumen, konsumen-produsen, dan produsenprodusen. Selama ini telah banyak penelitian yang mengkaji persaingan antara produsen dengan output sejenis. Namun, belum ada penelitian mengenai pola persaingan di antara perusahaan dengan output yang berbeda.

2. Dalam penelitian ini akan diteliti preferensi konsumen terhadap makanan cepat saji yang tidak sejenis, untuk mengetahui pola persaingan produsen-produsen dalam memperebutkan rupiah konsumen. Penggolongan besar hanya dilakukan terhadap kecepatan saji rumah makan, apakah termasuk golongan rumah makan cepat saji atau bukan.

\section{Tujuan Penelitian}

Sesuai dengan rumusan masalah di atas, maka tujuan penelitian ini adalah sebagai berikut:

1. Untuk mengidentifikasi faktor-faktor lingkungan yang paling penting yang menyebabkan ragam pada preferensi konsumen terhadap restoran cepat saji di Kota Bogor.

2. Untuk mengukur kinerja relatif atribut kepuasan konsumen di industri rumah makan cepat saji di Kota Bogor dengan menggunakan pendekatan importance performance analysis.

3. Untuk mengidentifikasi pola persaingan di antara rumah makan cepat saji di Kota Bogor dengan penggunaan metode scoring SPSS.

\section{LANDASAN TEORI \\ Tinjauan Pustaka \\ Preferensi Konsumen}

Dalam teori ekonomi modern, indeks utiliti adalah representasi dari preferensi ordinal konsumen. Para ahli membuat model maksimasi utiliti dengan menggunakan peralatan matematis karena dianggap sangat cocok untuk digunakan, yang jelas hasilnya tidak memilih angka tertinggi melainkan memilih mana yang bundle yang sangat sesuai dengan anggaran yang tersedia.

Indeks utiliti memberikan nilai angka pasti terhadap sesuatu yang dapat membandingkan kepuasan antar konsumen. Akan tetapi, selagi utiliti tidak terlihat tentunya sangatlah sulit imtuk mengukur permasalahannya dalam membangun satu set indeks cardinal utility tiap individu. Mungkin saja tiap orang dapat membentuk indeks tersebut sesuai dengan preferensi 
individu sehingga dapat diperbandingkan dengan yang lainnya. Hal ini sama dengan menyatakan bahwa tidak semua kepuasan dapat diukur dengan angka pasti apalagi dengan memberi kepuasan untuk masingmasing barang atau jasa. Untuk itu, utiliti atau kepuasan konsumen di dalam penelitian ini diukur berdasarkan ranking (ordo), dengan menggunakan metode Fishbein dan memanfaatkan skala Likert sebagai teknik kuantifikasi.

\section{Model Sikap Fischbein}

Model sikap Fischbein pada prinsipnya akan menghitung Ao (Attitude toward the Object), yaitu sikap seseorang terhadap sebuah objek, yang dikenali lewat atributatribut yang melekat pada obyek tersebut. Dengan mengenali sebuah obyek melalui cara melihat, meraba, mencoba dan menggunakan obyek itu untuk sekian waktu lamanya, maka seorang konsumen akan mempunyai sikap tertentu terhadap obyek dipakai atau digunakannya tersebut. Biasanya sebelum konsumen mengkonsumsi sebuah obyek tentunya ia memiliki suatu harapanharapan terhadap obyek tersebut. Sehingga setelah melihat, mencoba dan menggunakannya, konsumen tersebut dapat menilai apakah obyek yang bersangkutan telah sesuai dengan harapannya.

Dari pemaparan di atas, tampak ada dua komponen penting pada pengukuran sikap Fishbein, yaitu adanya evaluasi dan belief yang ada pada diri konsumen terhadap sebuah obyek tertentu.

Langkah-langkah dalam model Fischbein:

1. Menentukan Salient Belief

Setiap produk mempunyai banyak kriteria, namun akan lebih baik jika kepada konsumen (responden) ditanya tentang atribut yang relevan atau penting saja, yang disebut salient belief. Dalam penelitian ini ditentukan kriteria adalah keadaan restoran, menu makanan, harga, pelayanan, dan komunikasi.
2. Membuat Pertanyaan untuk Mengukur Belief

Setelah atribut ditentukan, konsumen akan ditanya bagaimana keyakinan (belief) terhadap atribut tersebut. Isi pertanyaan tentu tidak baku, hanya diusahakan mengukur keyakinan seseorang terhadap atribut obyek.

3. Membuat Pertanyaan untuk Mengukur Evaluation

Lain halnya dengan pengukuran belief, konsumen akan ditanya bagaimana evaluasinya terhadap atribut yang telah diukur belief-nya, apakah penting atau tidak. Untuk mengukur evaluasi tidak disebut produk merek tertentu, namun produk makanan cepat saji secara generik.

4. Mengukur Sikap terhadap Produk

Pengukuran sikap dilakukan dengan mengukur keseluruhan atribut (multiatribut), dengan rumus:

Ao $=f($ bi $x$ ei $)$

dimana:

- $A o=$ sikap terhadap produk

- $\quad b i=$ keyakinan konsumen terhadap atribut I dari produk rumah makan cepat saji, sebelum ia membeli atau mengkonsumsinya. o ei $=$ evaluasi konsumen terhadap atribut I dari produk rumah makan cepat saji secara umum tanpa dikaitkan dengan nama restoran tertentu o tanda $f=$ penjumlahan dari sejumlah atribut $\mathrm{I}$ yang dalam hal ini ada lima kriteria atribut.

\section{Importance Performance Analysis}

Menurut Martinez dalam Ariyoso (2009) menyebutkan bahwa "importance performance analysis" atau IPA telah diterima secara umum dan dipergunakan pada berbagai bidang kajian karena kemudahan untuk diterapkan dan tampilan hasil analisa yang memudahkan usulan perbaikan kinerja.

Adapun langkah-langkah analisis IPA adalah sebagai berikut: 
Mencari Harga Kesesuaian (dengan analisis IPA)

Tingkat kesesuaian adalah hasil perbandingan skor kinerja dengan skor kepentingan. Pada kasus bisnis multilevel marketing, untuk mengetahui apakah kinerja relathionship marketing pada bisnis multilevel marketing IPA sudah sesuai dengan kepentingan para membernya dan untuk mengetahui tingkat kepuasan para member ini dianalisis antara kepentingan dan pelayanan riil yang diwakilkan oleh huruf $Y$ dan $X$, dimana $X$ merupakan tingkat kinerja yang memberikan kepuasan member IPA, sedangkan $\mathrm{Y}$ merupakan tingkat kepentingan member IPA. Adapun rumus yang digunakan adalah 1:

$$
T k i=\frac{X_{i}}{Y_{i}} \quad x 100 \%
$$

Keterangan:

Tki = Tingkat kesesuaian responden .

$\mathrm{Xi}=$ Skor penilaian kinerja perusahaan

$\mathrm{Yi}=$ Skor penilaian kepentingan pelanggan

Sumbu mendatar (X) akan diisi oleh skor tingkat kinerja, sedangkan sumbu tegak (Y) akan diisi oleh skor tingkat kepentingan. Dalam penyederhanaan rumus, maka untuk setiap atribut yang mempengaruhi kepuasan konsumen dapat diketahui dengan rumus 2 :

$\bar{X}=\frac{\sum X_{i}}{n} \quad \bar{Y}=\frac{\sum Y_{i}}{n}$

Diagram kartesius digunakan untuk mengetahui indikator jasa pelayanan yang memuaskan atau tidak memuaskan konsumen. Rumus yang digunakan adalah 3:

$$
\overline{\bar{X}}=\frac{\sum_{i=1}^{N} \overline{X_{l}}}{K} \quad \overline{\bar{Y}}=\frac{\sum_{i=1}^{N} \bar{Y}_{l}}{K}
$$

dimana, $\mathrm{K}=$ Banyaknya atribut/fakta yang dapat mempengaruhi kepuasan pelanggan.

\section{Diagram Kartesius}

Diagram kartesius digunakan untuk memetakan atibut-atribut kualitas jasa pelayanan rumah makan cepat saji yang telah dianalisis, dengan gambar sebagai berikut:

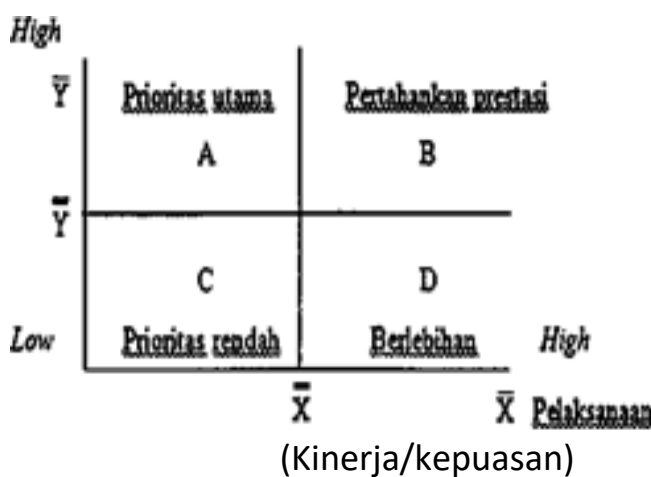

Keterangan:

A. Menunjukkan faktor atau atribut yang dianggap mempengaruhi kepuasan pelanggan, termasuk unsur-unsur jasa yang dianggap sangat penting, namun manajemen belum melaksanakannya sesuai dengan keinginan pelanggan sehingga mengecewakan/tidak puas.

B. Menunjukkan unsur jasa pokok yang telah berhasil dilaksanakan. Untuk itu wajib dipertahankannya. Dianggap sangat penting dan sangat memuaskan.

C. Menunjukkan beberapa faktor yang kurang penting pengaruhnya bagi pelanggan. Pelaksanaannya oleh perusahaan biasa-biasa saja. Dianggap kurang penting dan kurang memuaskan.

D. Menunjukkan faktor yang mempengaruhi pelanggan kurang penting, akan tetapi pelaksanaannya berlebihan. Dianggap kurang penting 
tetapi sangat memuaskan (J. Supranto, 2006).

\section{METODOLOGI PENELITIAN}

Studi ini melibatkan metode penelitian kualitatif maupun kuantitatif. Tahap awal berkaitan dengan identifikasi faktor-faktor yang dapat mengubah ragam preferensi konsumen terhadap rumah makan cepat saji di Kota Bogor. Tahap berikutnya adalah mengukur kineija relatif atribut kepuasan konsumen di industri rumah makan cepat saji di Kota Bogor dengan menggunakan pendekatan importance performance analysis, dan terakhir adalah mengidentifikasi pola persaingan di antara rumah makan cepat saji di Kota Bogor dengan penggunaan scoring SPSS.

\section{Lokasi Penelitian}

Penelitian ini diselenggarakan selama enam bulan, mulai bulan Juli hingga Desember 2015, dengan lokasi yang dipilih secara purposive, yaitu Kota Bogor.

\section{Teknik Pengumpulan Data \\ Populasi dan Sampel}

Penentuan contoh adalah proses memilih sejumlah elemen dari populasi target sehingga dengan berdasarkan analisis terhadap sampel yang memiliki karakteristik tertentu, akan dapat ditarik kesimpulan umum terhadap populasi. Menurut Surakhmad apabila jumlah populasi lebih dari 100 maka sampel yang diambil minimal $15 \%$ namun jika populasinya hanya mencapai 100 orang maka sedikitnya diperlukan $50 \%$ dari populasi yang dijadikan sampel ${ }^{4}$. Menurut teori Slovin ${ }^{5}$, jumlah sampel cukup menggunakan rumus seperti berikut:

$$
n=\frac{N}{N \cdot d^{2}+1}
$$

dimana:

$$
\begin{aligned}
& \mathrm{n}=\text { ukuran sampel } \\
& \mathrm{N}=\text { ukuran populasi } \\
& \mathrm{d}=\text { error/galat dugaan } \\
& \text { Data yang diperoleh kemudian }
\end{aligned}
$$
disusun dan disajikan dalam bentuk tabel dan grafik untuk menunjukkan nilai permukaan (face value). Agar tidak terjadi kekurangan data, kegiatan persiapan data yang harus dilakukan setelah data terkumpul adalah editing dan koding.

a) Editing adalah kegiatan awal yang dilakukan setelah data terkumpul. Lebih dikenal dengan istilah "melakukan editing data mentah". Tujuannya adalah untuk mengetahui kesalahan-kesalahan yang terdapat di dalam sampel, sehingga hasilnya akurat, konsisten dengan informasi lain, lengkap dan siap untuk dikoding dan ditabulasi.

b) Koding dilakukan untuk memudahkan pemasukan data ke dalam komputer atau lembar tabulasi. Dalam koding ada beberapa persyaratan yang harus dipenuhi, yaitu kesesuaian, klasifikasi, dan ketidakmenduaan (non ambigue).

c) Tabulasi data yang telah siap kemudian ditabulasi, disajikan dalam bentuk tabeltabel, untuk kemudian untuk kemudahan pemahaman nilai permukaan dapat disajikan dalam bentuk diagram.

\section{Teknik Pengumpulan Data}

Kuantifikasi dilakukan terhadap data kualitatif yang diperoleh dari angket yang dibangun. Untuk data kualitatif, dilakukan kuantifikasi melalui pembobotan skala Likert dengan sekala 1-5 (1 memberikan penilaian sangat tidak suka, dan 5 menunjukkan penilaian sangat suka). Kuesioner terdiri dari 3 halaman pertanyaan dan terdiri dari dua segmen pertanyaan yaitu penilaian expert (tingkat persaingan antar fast food) dan penilaian preferensi masyarakat. Kuesioner diberikan kepada pelanggan pada saat mereka telah selesai memesan menu makanan ataupun minuman dan menunggu untuk disajikan. Pengisian kuesioner 
membutuhkan kurun waktu 3-10 menit, sehingga pelanggan dapat dengan meluangkan waktu beberapa menit sembari menunggu menu pesanannya tiba. Analisis yang akan diterapkan untuk data tersebut adalah analisis deskriptif komparatif, analisis kesenjangan dan analisis proses hirarki. Tujuan penelitian ini adalah untuk mengetahui urutan atribut-atribut yang berpengaruh terhadap kualitas rumah makan cepat saji dan mengidentifikasi pola persaingan antar rumah makan cepat saji.

\section{Metode Analisis}

Metode analisis data yang akan diterapkan adalah analisis Fischbein analysis terdiri dari analisis kuantitatif dan analisis kualitatif.

\section{HASIL DAN PEMBAHASAN}

\section{Hasil Penelitian}

\section{Gambaran Umum Lokasi Penelitian Letak geografis}

Restoran cepat saji yang ada di Kota Bogor adalah jaringan restoran siap saji yang juga tersebar di seluruh daerah di Indonesia dan sebagian besar juga telah tersebar di berbagai belahan dunia. Produk yang dijual adalah bervariatif khusus untuk restoran cepat saji asing diantaranya terdapat jenis pizza, burger dan ayam goreng, sedangkan untuk restoran cepat saji domestik adalah rumah makan padang. Di Indonesia, restoran cepat saji ini memiliki lebih dari 100 outlet tersebar di kota besar maupun kecil.

Umumnya cabang restoran cepat saji berada dalam satu gedung pusat perbelanjaan, tempat- tempat strategis di pusat jantung kota yang tersebar di beberapa kota besar di Indonesia. Penelitian ini dilaksanakan di restoran cepat saji yang berada di Kota Bogor, dari beberapa restoran cepat saji yang ada, diambil sembilan restoran cepat saji yang dijadikan sebagai kajian penelitian, diantaranya adalah: Domino's, Pizza Hut, RM Trio, RM Lembah
Anai, RM Minang Raya, McD, Burger King, KFC, dan Texas Chiken.

\section{Karakteristik Responden}

Dari 30 responden, $66,67 \%$ laki-laki dan $33,33 \%$ perempuan, mayoritas berusia 25-39 tahun 50,00\%, 24 tahun atau kurang 40,00\%, dan $40-55$ tahun $10,00 \%$. Status pernikahan di dominasi konsumen dengan status belum menikah sebesar $63,33 \%$ dan sudah menikah sebesar $36,67 \%$. Pendapatan atau uang saku konsumen restoran kurang dari Rp10.000.000 (26,67\%), antara Rp11.000.000-Rp20.000.000 (43,33\%), antara Rp21.000.000-Rp30.000.000 (16.67\%) dan terakhir pendapatan di atas Rp31.000.000 (13,33\%). dengan frekuensi makan satu bulan tidak pernah sama sekali $(6,67 \%)$, satu kali dalam sebulan $(13,33 \%)$, dua sampai tiga kali dalam sebulan $(53,33 \%)$, lebih dari tiga kali dalam sebulan $(26,67 \%)$, dan pengeluaran sekali makan kurang dari Rp100.000 (33,33\%), Rp100.000-Rp200.000 (50\%), Rp200.000-Rp500.000 (10\%) dan lebih dari $\operatorname{Rp} 500.000$ (6.67\%).

\section{Hasil Uji Validitas dan Reliabilitas}

Pada penelitian ini, uji validitas dilakukan menggunakan program Microsoft Excel untuk menghitung nilai $r$ masing-masing variabel. Hasil perhitungan menunjukkan variabel yang digunakan memiliki rentang nilai $r$ hitung $0,593-0,855$. Hasil tersebut lebih besar $r$ tabel 0,318 ( $N=30$ dengan nilai kepercayaan 95\%), sehingga kuesioner yang digunakan pada penelitian ini valid. Selain memenuhi syarat validitas, kuesioner juga harus memenuhi syarat reliabilitas yang menunjukkan sejauh mana hasil suatu pengukuran yang dapat dipercaya (Rangkuti, 2002). Dari hasil perhitungan diketahui nilai $r$ hitung (ganjil-genap) $(0,899)$ lebih besar dari nilai $r$ tabel $(0,138)$. Hal tersebut menunjukkan bahwa alat ukur sudah reliabel.

\section{Penentuan Kriteria dan Atribut}

Penelitian ini berfokus pada lima kriteria utama yang dijadikan sebagai tolak 
ukur terhadap keluaran sebagai evaluasi baik itu kelebihan ataupun kekurangan dari masing-masing restoran cepat saji, dari ke lima kriteria tersebut yaitu:

1. Keadaan Restoran

Kriteria ini menjadi salah satu daya tarik tersendiri bagi konsumen khususnya, disamping produk yang dijual adalah dalam bentuk makanan, namun keadaan lingkungan baik dari tata letak ataupun pemanfaatan ruang sangat mempengaruhi terhadap konsumen akan keinginannya untuk kembali lagi ke tempat yang sama, konsumen merasa puas juga dapat mereferensikan baik kepada orang terdekat, teman ataupun rekan kerja. Berikut adalah bagian atribut dari keadaan restoran:

a. Bersih dan rapi.

b. Mudah mencari tempat duduk.

c. Sudah dikenal dengan baik (familiar).

d. Berada di lokasi yang mudah dijangkau.

e. Suasana restoran nyaman dan menyenangkan.

f. Piring makan, sendok, garpu, dan peralatan makan, bersih dan bagus.

g. Cocok untuk membawa anggota keluarga.

h. Memiliki toilet dan tempat cuci tangan yang bersih.

i. Restoran yang nyaman untuk anak kecil.

j. Memiliki dekorasi yang menarik perhatian (atraktif).

k. Memiliki tempat duduk yang nyaman.

I. Menyediakan fasilitas internet (Wifi).

m. Memiliki tempat parkir yang nyaman dan aman.

2. Menu Makanan

Menu makanan adalah salah satu andalan dan ciri khas tertentu dari masing-masing restoran cepat saji, setidaknya menu harus dibuat secara variatif dan selalu menonjolkan tingkat kecirikhasan dari masakan yang dimiliki, peka terhadap selera pasar dan ditambah dengan inovasi yang berkesinambungan agar konsumen tidak mudah bosan dengan menu-menu yang dimiliki sebuah restoran cepat saji akan menjadikan rumah makan yang selalu digemari oleh konsumen berikut termasuk atribut dari menu, makanan:

a. Mengandung gizi yang jelas dan dapat terukur.

b. Dapat menimbulkan selera makan.

c. Kombinasi makanan yang serasi selaras.

d. Menawarkan menu yang tidak membosankan.

e. Menawarkan menu yang telah disesuaikan dengan selera local.

f. Sesuai waktu makan (sarapan, makan siang, makan malam).

g. Menawarkan makanan lain yang unik dan lezat.

h. Menawarkan hidangan penutup yang dingin.

i. Menawarkan hidangan penutup yang panas.

3. Harga

Menetapkan program-program dalam penetapan harga memberikan nilai tambah dalam memudahkan menetukan transaksi pembelian, kemudahan yang ditawarkan akan membuat konsumen merasa puas, harga yang teijangkau dan sesuai dengan sajian yang diharapkan menciptakan sebuah customer loyalty yang menguntungkan bagi rumah makan cepat saji. Penetapan atribut harga meliputi:

a. Sesuai dengan kualitas makanan dan suasana.

b. Menawarkan diskon dan kupon makan.

c. Sering menawarkan undangan makan gratis.

d. Menawarkan diskon untuk pembayaran menggunakan kartu kredit.

e. Mengadakan program makan sepuasnya satu harga. 
f. Relatif murah untuk kualitas dan suasana yang ditawarkan.

4. Pelayanan

Jenis pelayanan harus benar-benar memiliki nilai tambah tersendiri yang diberikan bagi kepuasan pelanggan, pelayanan yang prima dan selalu mengedepankan pelanggan nantinya akan memberikan sebuah efek positif bagi berkelanjutannya hubungan yang simbiosis mutualisme antara produsen dan konsumen. Ada beberapa atribut penting. berkaitan dengan pelayan yaitu sebagai berikut:

a. Menyediakan pelayanan yang cepat dan efisien.

b. Delivery order yang mudah dan tepat waktu.

c. Penampilan karyawan rapi dan sopan.

d. Pelayanan dari karyawan yang terampil.

e. Pelayanan dari karyawan yang ramah.

f. Menyampaikan pesanan sesuai dengan yang dijanjikan.

g. Ketepatan waktu penyerahan makanan sesuai janji.

h. Menyediakan sistem pemesanan tempat.

5. Komunikasi.

Hal ini menjadi sebuah pelengkap bagi sebuah manajemen bisnis yang memberikan informasi secara langsung terhadap calon konsumen, dikemas dalam beberapa cara yang mengedepankan aspek pemasaran terhadap produk yang akan ditawarkan kepada konsumen. Caracara tersebut dikemas dalam beberapa atribut, yaitu:

a. Telah memiliki pengalaman dan citra yang baik.

b. Brosur, menu mengesankan seperti restoran bertaraf internasional.

c. Sering memasang iklan di media elektronik Radio.

d. Sering memasang iklan di media elektronik TV. e. Sering memasang iklan di media sosial berbasis internet.

f. Sering menyebarkan leaflet/brosur.

g. Sering memasang iklan di media cetak (koran, majalah).

Setelah rincian atribut masing-masing kriteria tersebut ditentukan dengan baik, responden diarahkan untuk menentukan seberapa besar ekspektasi mereka terhadap atribut yang ada dengan menggunakan skala Likert. Ketika data preferensi dari atribut telah terkumpul, pelanggan juga diminta untuk mengisi data demografi dari setiap pelanggan yang mengisi kuesioner, isi dari data tersebut diantaranya:

1. Lokasi tempat tinggal.

2. Status pernikahan.

3. Umur.

4. Jumlah anggota keluarga di bawah 18 tahun.

5. Pendapatan rata-rata per tahun.

6. Intensitas makan di restoran dalam seminggu.

7. Intensitas makan di restoran dalam sebulan.

8. Rata-rata pengeluaran yang dikeluarkan setiap makan direstoran cepat saji.

Data-data demografi ini dapat dimanfaatkan untuk mengetahui segmen pasar ataupun potensi pasar yang dimiliki dan nantinya akan dipetakan untuk bisa dibidik menjadi pangsa pasar utama. Inilah yang nantinya menjadi sebuah keuntungan dari sebuah pengelolaan manajemen bisnis dari perusahaan rumah makan cepat saji.

\section{Metode Fischbein}

Dari hasil tersebut dapat disimpulkan bahwa atribut menawarkan diskon untuk pembayaran menggunakan kartu kredit adalah strategi yang baik untuk menarik konsumen kembali lagi melakukan pembelian, berada pada posisi teratas dengan poin tertinggi yaitu 3,2 memiliki kinerja terbaik dan dapat mempengaruhi persepsi dari konsumen. Oleh karena itu diharapkan manajemen sekiranya dapat 
membuat sebuah promo-promo kemudahan dalam bertransaksi bagi konsumen kedepannya lagi.

Menjadi konsen yang sangat vital bagi manajemen adalah tentang keadaan restoran yang harus bersih dan rapi, ini berada pada posisi yang paling akhir diantara ke 42 atribut yang lainnya (poin 1,47). Faktor kebersihan harus dapat dikedepankan karena konsep dari rumah makan cepat saji lebih banyak menarik konsumen dari tingkat ekonomi menengah ke atas, dan tentunya begitu kritis memberikan penilaian terhadap kondisi atau keadaan di seluruh aspek layanan dari rumah makan cepat saji.

\section{Analisis Evaluasi}

Dari analisa yang telah dilakukan terlihat bahwa atribut model penawaran diskon untuk pembayaran menggunakan kartu kredit memiliki tingkat kepentingan tertinggi yang kemudian diikuti dengan model atribut yang lain. Bertransaksi dengan menggunakan kartu kredit lebih digemari dan menanamkan intensitas belanja yang berlanjut kedepannya, meskipun poin kepentingan $(2,53)$ masih di bawah poin kinerja $(3,2)$. Namun hal ini menandakan bahwa konsumen mendapatkan kemudahan bertransaksi ditambah dengan pemberian diskon menjadikan konsumen tanpa berfikir ulang untuk berbelanja dengan puas akan memenuhi kebutuhannya. Poin terendah berada pada atribut bersih dan rapi $(1,27)$ tingkat kepentingan yang juga masih di bawah tingkat kinerja $(1,47)$. Koreksi harus segera dilakukan oleh pihak manajemen, segera perbaiki lini tersebut untuk mengoptimalkan fungsi kinerja dari karyawan sebelum konsumen enggan untuk datang kembali.

\section{Analisis Sikap Konsumen}

Setelah dilakukan perhitungan maka Ao (sikap konsumen) dapat ditetapkan keseluruhan sebesar 180,27. Angka tersebut tidak dapat diartikan secara tepat, kecuali bila angka sikap tersebut dibandingkan dengan angka sikap untuk rumah makan lainnya. Pada konteks ini pengukuran sikap konsumen dilakukan secara keseluruhan terhadap semua atribut, dapat diartikan juga konsumen tidak suka akan atribut tertentu yang diberikan oleh pihak fast food, namun konsumen tetap menyukai atribut lain yang juga ditawarkan oleh pihak fast food.

\section{Importance Performance Analysis (Analisis (PA")}

Analisa IPA dilakukan sebagai masukan terhadap manajemen akan usulan perbaikan kerja atas atribut-atribut yang diberikan kepada konsumen apakah dari atribut-atribut tersebut sudah memiliki penilaian yang baik bagi konsumen atau justru tidak memiliki nilai pendongkrak bagi jasa pelayanan yang telah diberikan.

Secara keseluruhan dapat diartikan bahwa tingkat jasa pelayanan yang diberikan kepada konsumen sebagian besar atribut berada pada matriks posisi prioritas rendah dengan persentase $53 \%$, atribut pada matriks pertahankan prestasi berada di urutan kedua dengan persentase $33 \%$, dilanjutkan dengan atribut prioritas utama hanya ada $9 \%$ dan terakhir atribut pada matriks berlebihan dengan persentase 5\%. Ini artinya masih banyak atribut yang tidak memiliki efektifitas yang signifikan terhadap jasa pelayanan yang diberikan dari masing-masing atribut. Kedepannya agar dapat dijadikan acuan untuk perbaikan dari setiap atribut yang memiliki tingkat prioritas rendah agar dapat memberikan jasa pelayanan dan kinerja yang lebih baik lagi.

\section{Penilaian Tingkat Preferensi Seluruh Responden}

Hasil penilaian tingkat preferensi oleh 30 responden restoran cepat saji menunjukkan bahwa kriteria harga memiliki nilai rata-rata tertinggi $(61,17)$ dibanding empat kriteria lain (tabel 5). Mayoritas responden memilih makan di restoran cepat 
saji dikarenakan terdapat harga diskon khusus bagi pembayaran menggunakan kartu kredit dengan poin rata-rata tertinggi $(2,53)$. Promosi menjadi daya tarik yang memikat bagi para pelanggan untuk kembali lagi demi tingkat kepuasan berbelanja/bertransaksi. Park (2004) menambahkan promosi menjadi salah satu atribut penting dalam restoran fast food.

Penilaian tiap atribut dari setiap kriteria menunjukkan tiga atribut dengan nilai kepentingan tertinggi berasal dari kriteria harga yang ditawarkan, yaitu menawarkan diskon untuk pembayaran menggunakan kartu kredit $(2,53)$, sering menawarkan undangan makan gratis $(2,27)$, serta mengadakan program makan sepuasnya satu harga $(2,20)$. Konsumen menilai tiga atribut perlu dipertimbangkan dalam memilih restoran.

Bentuk pelayanan meliputi menyediakan pelayanan yang cepat dan efisien $(1,30)$, menyampaikan pesanan sesuai dengan yang dijanjikan $(1,40)$, pelayanan dari karyawan yang ramah $(1,43)$, penampilan karyawan rapi dan sopan $(1,47)$, ketepatan waktu penyerahan makanan sesuai janji $(1,47)$, pelayanan dari karyawan yang terampil $(1,50)$, menyediakan sistem pemesanan tempat $(1,73)$, serta delivery order yang mudah dan tepat waktu $(1,77)$, secara kumulatif memperoleh nilai rata-rata terendah $(39,86)$. Data ini menunjukkan konsumen tidak begitu puas akan pelayanan dari karyawan yang diberikan dari rumah makan cepat saji. Seharusnya ini dapat dijadikan perhatian manajemen untuk perbaikan tata kelola pelayanan agar lebih baik lagi. Konsep rumah makan cepat saji adalah mengedepankan kecepatan pelayanan demi mengefisienkan waktu, membutuhkan perubahan yang harus segera dilaksanakan demi menjaga pelanggan agar tetap loyal terhadap pelayanan yang diberikan. Hal ini bertujuan sebagai bentuk ganti rugi jika konsumen merasa tidak puas terhadap komponen yang ada pada restoran, sehingga konsumen akan mempertimbangkan restoran cepat saji dalam daftar pilihan restoran yang mereka kunjungi.

\section{Tingkat Persaingan}

Posisi Relatif Pesaing (Kemudahan Dicapai)

Nampak pada urutan pertama di miliki oleh restoran cepat saji KFC dengan poin $(3,76)$ disusul oleh rumah makan yang lainnya. Posisi yang strategis dan mudah dijangkau memberikan kemudahan bagi konsumen untuk datang demi mengkonsumsi hidangan yang ditawarkan oleh pihak rumah makan cepat saji.

\section{Jarak antara Pusat Kegiatan (Kedekatan dari Rumah, Kantor, Sekolah)}

Jarak antara pusat kegiatan dapat menentukan konsumen dalam memilih restoran cepat saji baik dekat dengan pusat keramaian, rumah, kantor ataupun sekolah. Dalam analisa ini rumah makan Trio dan KFC berada dalam urutan tertinggi dengan poin 2,58 , karena rumah makan tersebut berada di pinggir jalan raya yang ramai dilalui kendaraan dan tidak jauh dari pusat kegiatan seperti rumah, kantor atau sekolah sehingga hal tersebut memudahkan konsumen untuk menemukan dan menjangkau restoran tersebut.

\section{Tingkat Persaingan antar Rumah Makan Cepat Saji di Kota Bogor}

Dari hasil analisis yang dilakukan terhadap sembilan rumah makan cepat saji terhadap variabel yang diteliti, maka dapat ditentukan rata-rata total scoring yaitu rumah makan KFC sebesar $(20,56,14 \%)$, rumah makan McD sebesar (18,29, 12\%), rumah makan Pizza Hut $(16,67,11 \%)$, rumah makan Texas Chiken (16,67, 11\%), rumah makan Trio $(15,98,11 \%)$, rumah makan Simpang Raya $(15,96,11 \%)$, rumah makan Burger Kings $(15,87,10 \%)$, rumah makan Lembah Anai $(15,18,10 \%)$, dan rumah makan Dominos $(14,83,10 \%)$. 


\section{KESIMPULAN DAN SARAN \\ Kesimpulan}

1. Dari analisa yang telah dilakukan terdapat lima atribut tertinggi yang diberikan penilaian oleh konsumen terhadap kinerja yang diberikan oleh restoran cepat saji yaitu menawarkan diskon untuk pembayaran menggunakan kartu kredit $(3,2)$, sering menawarkan undangan makan gratis $(3,1)$, mengadakan program makan sepuasnya satu harga $(2,93)$, menawarkan hidangan penutup yang panas $(2,77)$ dan Sering memasang iklan di media elektronik Radio $(2,73)$. Penilaian terhadap tingkat kepentingan diperoleh lima atribut dengan nilai tertinggi yaitu menawarkan diskon untuk pembayaran menggunakan kartu kredit (2,53), menawarkan hidangan penutup yang panas $(2,3)$, sering memasang iklan di media elektronik Radio (2,3), sering menawarkan undangan makan gratis $(2,27)$, mengadakan program makan sepuasnya satu harga $(2,2)$. Untuk atribut dengan penilaian lebih rendah dari penilaian ke lima atribut baik dinilai dari tingkat kinerja maupun dari tingkat kepentingan di atas perlu segera dilakukan perbaikan. Ke lima atribut teratas tersebut juga bukan dalam artian sudah cukup memuaskan akan hasil dari tingkat penilaian kinerja dan tingkat kepentinga yang diperoleh, namun harus dijaga dan lebih ditingkatkan lagi demi menjaga kepuasan atas seluruh pelayanan yang diberikan oleh pihak rumah makan cepat saji.

2. Analisa IPA dilakukan sebagai masukan terhadap manajemen akan usulan perbaikan kinerja atas atribut-atribut yang diberikan kepada konsumen apakah dari atribut-atribut tersebut sudah memiliki penilaian yang baik bagi konsumen atau justru tidak memiliki nilai pendongkrak bagi jasa pelayanan yang telah diberikan. dari hasil perhitungan dapat ditentukan titik masing- masing sumbu dari setiap atribut, dengan hasil tersebut dapat dikelompokkan dari 43 atribut menjadi empat kuadran berdasarkan tingkat kepentingan, diantaranya: prioritas utama (4 atribut), pertahankan prestasi (14 atribut), prioritas rendah (23 atribut) dan berlebihan (2 atribut), dengan demikian dapat membantu manajemen untuk menentukan langkah-langkah memperkuat setiap lini atribut bagi yang memiliki penilaian kurang baik dan lebih meningkatkan lagi aspek pelayanan atribut yang telah memiliki penilaian sesuai harapan konsumen.

3. Berkaitan dengan tingkat persaingan antar rumah makan cepat saji, diperoleh hasil scoring pada SPSS tingkat persaingan yang sangat kompetitif, perhitungan dari rata-rata sembilan variabel dari sembilan rumah makan cepat saji yang ada di Kota Bogor dipetakan dengan urutan dari tertinggi hingga terendah, dari hasil analisis yang dilakukan terhadap sembilan rumah makan cepat saji terhadap atribut yang diteliti, maka dapat ditentukan rata-rata total scoring yaitu rumah makan KFC sebesar (20,56), rumah makan McD sebesar $(18,29)$, rumah makan Pizza Hut $(16,67)$, rumah makan Texas Chiken $(16,67)$, rumah makan Trio $(15,98)$, rumah makan Simpang Raya $(15,96)$, rumah makan Burger Kings (15,87), rumah makan Lembah Anai $(15,18)$, dan rumah makan Dominos $(14,83)$.

\section{Saran}

1. Atribut dengan penilaian berdasarkan kinerja dan kepentingan masih perlu dilakukan perbaikan, baik yang telah mendapatkan nilai terbaik dari masingmasing tolak ukur yang dinilai dari tingkat kinerja ataupun dari tingkat kepentingan misalkan dari atribut penetapan harga 
dapat memberikan keterjangkauan dan kemudahan dalam bertransaksi, memberikan promo-promo khusus pembelian bagi konsumen, dari kriteria komunikasi hendaknya meningkatkan intensitas promosi, terutama iklan di televisi dan turut berpartisipasi dalam acara besar di wilayah sekitar outlet, kemudian dari kriteria menu makanan agar dijaga kualitas masakan dan selalu berinovasi menyesuaikan dengan tingkat selera konsumen, harus menjadi sebuah tolak ukur atau target pencapaian dimana nilai maksimal dari skala Likert adalah poin 5 , oleh karena itu penilain atributatribut yang belum maksimal setidaknya harus segera dilakukan perubahan ke arah perbaikan yang dapat membangun sebuah sistem bisnis simbiosis mutualisme antara konsumen dan pelaku bisnis rumah makan cepat saji.

2. Hasil dari pengukuran atribut dari masing-masing kriteria, nampak pembagian atas kuadran kartesius yang telah dihitung berdasarkan tingkat kinerja dan kepentingan dari masing-masing atribut. Dari Kuadran A (prioritas utama) agar kiranya manajemen segera merealisasikan ke empat atribut yang ditawarkan oleh pihak rumah makan cepat saji, karena konsumen menganggap unsur-unsur atribut ini sangat penting untuk direalisasikan. Dari Kuadran B (pertahankan prestasi) menunjukkan unsur atribut yang telah berhasil dilaksanakan (14 atribut). Untuk itu wajib dipertahankan dan ditingkatkan lagi, karena dianggap sangat penting dan sangat memuaskan. Dari kuadran C (prioritas rendah) menunjukkan beberapa faktor yang kurang penting pengaruhnya bagi pelanggan. Pelaksanaannya dari atribut tersebut biasa- biasa saja. Dianggap kurang penting dan kurang memuaskan. Segera lakukan perbaikan dari segi kinerja atau jika memang tidak terlalu signifikan hasilnya sebaiknya agar ditiadakan atribut-atribut tersebut (23 atribut). Dari kuadran D (berlebihan), menunjukkan faktor yang mempengaruhi pelanggan kurang penting, akan tetapi pelaksanaannya berlebihan. Dianggap kurang penting tetapi sangat memuaskan. Tetap diadakan sebagai nilai tambah dari tingkat pelayanan yang ditawarkan (2 atribut).

3. Pola persaingan yang begitu ketat antar rumah makan cepat saji memang didominasi dari rumah makan cepat saji berlabel asing dibandingkan domestik, sekiranya lebih jeli lagi akan penilain yang telah diberikan dari analisa ini, ambil langkah cepat akan variabel yang menjadi nilai positif diberikan konsumen terhadap rumah makan sebagai kekuatan untuk meraup pangsa pasar dan segera memperbaiki nilai variabel yang memiliki penilain yang lemah akan operasional kerja yang dilakukan oleh pihak rumah makan cepat saji. Rumah makan cepat saji yang berada pada posisi teratas menjalankan fungsi rata-rata dari 9 variabel lebih baik dari ke delapan pesaing lainnya. Seharusnya hal tersebut dapat dijadikan sebuah referensi akan perubahan-perubahan yang signifikan dan terukur dari sistem operasional pelayanan jasa rumah makan cepat saji lainnya agar dapat menarik konsumen lebih banyak lagi.

\section{DAFTAR PUSTAKA}

Abdi, H., dan Valentin, D. (2007). "DISTATIS", Encyclopedia of Measurement and Statistics, Ed: Salkind, N., Sage Publications, Inc., California, hal. 284-291.

Gabriel, K.R. 1971. "The Biplot Graphic Display of Matrices with Application to Principal Component Analysis", Biometrika, Vol. 58, No. 3, hal. 453467.

Ginanjar, I. 2011. "Analisis Produk dan Assessor dari Data Penyortiran 
Menggunakan Hybrid DISTATIS", Prosiding Seminar Nasional Statistika, Universitas Diponegoro, ISBN: 978- 979-097-142-4, hal. 2537.

Greenacre, M.J. 1984. Theory and Applications of Correspondence Analysis, Academic Press, Inc., London.

Harshman, R.A., dan Lundy, M.E. 1994. "PARAFAC: Parallel Factor Analysis", Computational Statistics and Data Analysis, Vol. 18, hal. 39-72.

Husson, F., \& Pages, J. 2006. "INDSCAL Model: Geometrical Interpretation and Methodology", Computational Statistics and Data Analysis, Vol. 50, hal. 358-378.

Kotler, P. 1997. Marketing Management, 6th edition, Prentice-Hall, Inc., New Jersey. Kruskal, J., dan Wish, M. (1978), Multidimensional Scaling, Sage University Papers Series.

Quantitative Applications in the Social Sciences; No. 07-011, Sage Publications, Inc., lowa.

Lawless, H.T., Sheng T., dan Knoops, S. 1995. "Multidimensional Scaling of Sorting Data Applied to Cheese Perception", Food Quality and Preference, Vol. 6, hal. 91-98.

Levitt, T. 1980. "Marketing Succes Through Differentiation of Anything", Harvard Business Review, JanuaryFebruary 1980, Harvard Business School Publishing, Boston. Goldberg, Jack.L., 1991. Matrix Theory With Apllications, McGrawHill Inc, New York.

Meyners, M., Kunert, J., dan Qanari E.M. 2000. "Comparing Generalized Procrustes Analysis and Statis", Food Quality and Preference, Vol. 11, hal. 77-83.

Yan, W., and Kang, M.S. 2003. GGE Biplot Analysis: A Graphical Tool for
Breeders, Geneticists, and Agronomists, CRC Press LLC, Florida. 